\title{
Myeloblasts Under 20 Percent of Bone Marrow Nucleated Cells
}

National Cancer Institute

\section{Source}

National Cancer Institute. Myeloblasts Under 20 Percent of Bone Marrow Nucleated

Cells. NCI Thesaurus. Code C36216.

A semi-quantitative microscopic finding indicating less than 20 percent of the nucleated cells in a bone marrow sample are immature mononuclear cells of myeloid origin. 